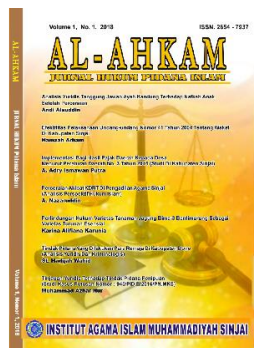

Homepage : $\underline{\text { http://journal.iaimsinjai.ac.id/index.php/al-ahkam/index }}$

\title{
Eksistensi Politik Hukum Dari Peraturan Pemerintah Nomor 24 Tahun 2018 Tentang Penataan Perizinan Berusaha Terintegrasi Secara Elektronik
}

\author{
${ }^{1}$ Tri Dian Aprilsesa, ${ }^{2}$ Edy Suasono \\ ${ }^{1}$ Universitas Tanjungpura, Alamat : Jl. Prof. Dr. H. Hadari Nawawi, Bansir Laut, Kota Pontianak. \\ ${ }^{2}$ Universitas Tanjungpura, Alamat : Jl. Prof. Dr. H. Hadari Nawawi, Bansir Laut, Kota Pontianak. \\ Email:diantriaprilsesa@hukum.untan.ac.id,
}

\begin{abstract}
Abstrak
Perubahan lingkungan sangat berpengaruh dalam sikap dan perlindungan pada manusia. Alam yang ada dapat dimanfaatkan demi kepentingan manusia untuk menjadi lebih baik dan sehat atau malah sebaliknya. Apabila alam tidak dimanfaatkan secara baik dan benar maka dapat merusak dan bahkan bisa menjadi malapetakan bagi semua mahluk hidup. Pemerintah mengeluarkan Peraturan Pemerintah Nomor 24 tahun 2018 tentang Penataan Perizinan Berusaha Terintegrasi Secara Elektronik. Maksud dan tujuan dikeluarkannya Peraturan Pemerintah ini ialah dalam rangka penataan, percepatan, serta kenaikan penanaman modal serta berupaya, perizinan berupaya yang diterbitkan oleh departemen/lembaga serta pemerintahan. Beberapa pengaturan telah dicoba dalam sistem dan regulasi pelayanan, yang dapat memenuhi kebutuhan dunia usaha, perkembangan teknologi dan persaingan global. Dalam perlindungan dan pengelolaan lingkungan, penempatan dan penempatan AMDAL dan UKL-UPL merupakan prasyarat untuk mendapatkan izin lingkungan. Artinya kajian AMDAL dan UKL- UPL dicoba terlebih dahulu secara benar dan sehabis ada anjuran layak area dari Komisi Penilai Amdal, sampai anjuran ini dijadikan dasar buat menerbitkan izin lingkungan. Berbeda dengan kaedah hukum yang ada dalam PP Nomor 24 Tahun 2018, izin lingkungan diterbitkan dahulu baru AMDAL, UKL-UPL menyusul. Selain itu kaedah hukum yang ada dalam PP Nomor 24 tahun 2018 penyusunan tidak sesuai dengan logika hukum atau bertentangan dengan doktrin Hukum Administrasi Negara.
\end{abstract}

Kata Kunci : Politik Hukum Perinzinan Berusaha

\section{Pendahuluan}

Berbagai macam regulasi yang dikeluarkan oleh pemerintah sebagai konsekuensi dari negara hukum, dimaksudkan untuk memberikan arah dan dasar hukum bagi pembagunan disegala bidang. Berbagai macam kebijakan pembangunan telah luncurkan oleh pemerintah yang salah satunya di bidang ekonomi. Kebijakan pembangunan sektor ekonomi menitikberatkan pada Kebijakan Nawasita jilid kedua, yang berkaitan dengan pembangunan industri dengan 3 tujuan terutama untuk meningkatkan produktivitas, meningkatkan daya saing, dan memperkuat industri yang 


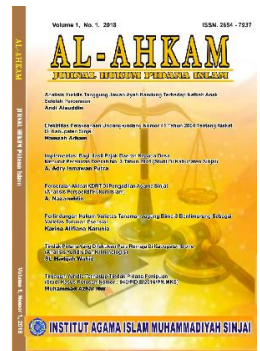

Al-Ahkam

Jurnall Hukum Pidana Islam

Volume 3, No. 1, 2021

ISSN (print) : 2654-7937

ISSN (online) : 2715-0313

Homepage : $\underline{\text { http://journal.iaimsinjai.ac.id/index.php/al-ahkam/index }}$

strategis. 6 langkah strategis akan didukung dalam focus kebijakan yang ada, salah satunya adalah memperkuat lingkungan investasi. ${ }^{1}$

Pemerintah menghasilkan mengenai penyiapan, percepatan dan peningkatan pengaturan investasi dan energi untuk pengaturan perizinan upaya komprehensif elektronik pada PP No. 24 tahun 2018. Izin komersial yang dikeluarkan oleh departemen / lembaga dan pemerintah daerah sebagai sistem dan regulasi pelayanan yang memenuhi persyaratan dunia usaha, perkembangan teknologi dan persaingan global.

Setiap peraturan perundang-undangan dihentikan, berbagai peraturan terkait harus ditetapkan atau diperhatikan secara vertikal maupun horizontal untuk menghindari benturan peraturan atau tumpang tindih antara satu pilar dengan pilar lainnya. Dengan demikian, pelaksanaannya memberikan kejelasan dan kepastian hukum bagi perangkat pelaksana dan masyarakat.

Dari segi ilmu dan regulasi perundang-undangan (UU No.12 Tahun 2011), banyak terdapat kendala dalam rumusan Peraturan Pemerintah Nomor 24 Tahun 2018 tentang pelayanan perizinan e-commerce secara komprehensif, atau justru tidak sesuai dengan ketentuan hokum yang berlaku. Prinsip hukum dan peraturan mengabaikan berbagai peraturan perundang-undangan terkait.

Konsep negeri hukum merupakan sesuatu sistem nasional yang diatur bersumber pada hukum yang berlaku, berkeadilan serta terdiri dari konstitusi yang ada. Semua orang di negara itu, baik yang diperintah atau memerintah, harus mematuhi segala hukum sehingga setiap orang diperlakukan sama. Terlepas dari warna kulit, ras, jenis kelamin, agama, wilayah, dan proporsi kekuasaan pemerintah dibatasi menurut prinsip pembagian kekuasaan, sehingga pemerintah tidak mengambil tindakan sewenangwenang, agar masyarakat dapat mengambil tempat dalam ilmu secara demokratis dan berfungsi secara profesional. (Izhandri, Kn and Agustina, 2018)

Perizinan lingkungan hidup untuk pemerintah ialah instrumen yuridis preventif buat mengatur prilaku warga dalam rangka melakukan proteksi serta pengelolaan area hidup, sebab lingkungan hidup yang bersih serta sehat sebagai hak asasi setiap rakyat sebagaimana diamanatkan dalam Konstitusi Pasal $28 \mathrm{H}$. Metode pemerintah dalam mengatur prilaku warga ialah dengan menetapkan bermacam berbagai persyaratan yang disesuaikan dengan spesifikasi bidang yang hendak diberikan izin.

Penyusunan peraturan pemerintah ini tentang pelayanan perizinan berusaha terintegrasi secara elektronik dilihat dari ilmu perundang-undangan dan ketentuan pembentukan peraturan perundang-undangan (UU No 12 Tahun 2011) terdapat berbagai persoalan atau dengan kata lain secara substansi tidak mengindahkan asas pembentukan peraturan perundang dan mengabaikan berbagai peraturan yang terkait yang ada.

\footnotetext{
${ }^{1}$ https://www.alinea.id/bisnis/ini-program-ekonomi-jokowi-dalam-nawacita-jilid-ii-b1Xbu9hTo, diakses 29 april 2020.
} 


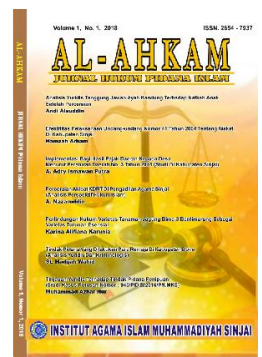

Dari bermacam definisi tentang politik hukum yang di informasikan oleh para sarjana mempunyai arti yang sama ialah hukum dan kebijakan yang harus dilaksanakan atau tidak dilaksanakan untuk mencapai tujuan negeri. Oleh karena itu, hukum sebagai alat untuk suatu pencapaian yang telah ditetapkan.

Politik hukum muncul dalam lingkungan hidup selaku menghasilkan produk baru buat mengendalikan hukum lingkungan hidup. Namun dalam perizinan berupaya lingkungan hidup ini politik hukum lebih memandang dari perkembangan ekonomi buat menarik investasi yang besar dari luar negeri. Sehingga amdal sendiri dinilai sebagai penghambat buat para investor.

\section{Metode Penelitian}

Sesuai dengan judul serta kasus yang ada, sehingga metode penelitian ini yang digunakan dengan metode hukum normatif. Metode hukum normatif dicoba lewat riset pustaka yang menelaah (paling utama) bahan hukum primer serta sekunder. Bersumber pada perihal tersebut periset tertarik buat mengkaji secara normatif tentang Politik Hukum Terhadap Peraturan Pemerintah Nomor 24 Tahun 2018 tentang Penyusunan Perizinan Berupaya terintegrasi Secara Elektronik dalam hubungannya dengan proteksi serta pengelolaan lingkungan hidup.

\subsection{Jenis Pendekatan}

Dalam penelitian ini peneliti menggunakan beberapa metode yaitu:

1. Pendekatan filosofis, yang digunakan untuk mengevaluasi arah atau kebijakan peraturan yang ada dalam penelitian ini.

2. Pendekatan peraturan perundang-undangan, yang digunakan untuk menganalisis dan mengkaji isi dari Perspektif Sinkronisasi Vertikal dan Horizontal serta Peraturan Perundang-undangan terkait.

3. Pendekatan konseptual yang menggunakan konsep atau teori untuk mengkaji pada implikasi peraturan berizin dan berusaha.

Penelitian ini dilakukan dengan penelitian hukum normatif deskriptifpreskriptif, dan data dianalisis secara kualitatif. Pendekatan yang dilakukan adalah abstrak, artinya mengumpulkan dan menyeleksi data yang dikumpulkan untuk mencari data, khususnya data yang berkaitan dengan objek penelitian.

\section{Hasil Penelitian}

Lingkungan hidup merupakan suatu kesatuan ruang dengan segala yang ada di bumi, yang akan mempengaruhi alam itu sendiri, kelangsungan hidup, dan kesejahteraan manusia serta makhluk hidup lainnya. Definisi ini menunjukkan bahwa lingkungan suatu sistem biologis yang terdiri dari berbagai faktor, baik berupa biologis (komunitas biologis) maupun benda mati (komunitas non-biologis), keberadaannya saling berhubungan secara seimbang.

Dilihat dari segi perspektif hukum administrasi nasional, ada beberapa undangundang yang perlu kita perhatikan. Pada prinsipnya perizinan merupakan pembatasan hak asasi manusia sebagai alat kontrol, oleh karena itu setiap instansi yang menentukan perizinan harus diawasi dalam peraturan pemerintah yang tertulis serta disetujui oleh wakil rakyat. Izin usaha dalam sistem online single submission (OSS) telah mendapat 


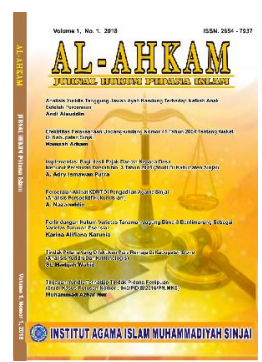

\section{Al-Ahkam}

Jurnal Hukum Pidana Islam

Volume 3, No. 1, 2021

ISSN (print) : 2654-7937

ISSN (online) : 2715-0313

Homepage : $\underline{\text { http://journal.iaimsinjai.ac.id/index.php/al-ahkam/index }}$

legitimasi (PP 24/2018), yang tentunya menyalahi sebagian kewenangan, terutama landasan hukumnya. Peraturan perundang-undangan pemerintah tentang legalitas OSS tidak dibuat berdasarkan persetujuan perwakilan rakyat. Kewenangan organisasi OSS yang diperoleh melalui legitimasi peraturan pemerintah tidak berlaku karena melanggar komponen dasar kewenangan hukum. Pembatalan izin dalam lisensi mengakibatkan tidak validnya izin.

Keberadaan tiap faktor dalam lingkungan hidup wajib dapat dipastikan, baik dari segi kuantitas ataupun kualitasnya supaya baku kualitas lingkungan hidup bisa terpelihara dengan baik. Buat memperoleh kualitas lingkungan yang baik butuh memperoleh sesuatu upaya ataupun kebijakan pengelolaan lingkungan yang sistematik komprehensif. Pengelolaan lingkungan hidup bisa diartikan sebagai upaya kesadaran untuk memelihara ataupun membetulkan kualitas lingkungan supaya kebutuhan dasar kita bisa terpelihara dengan baik. Secara normatif penafsiran tentang proteksi serta pengelolaan lingkungan hidup sudah diformulasikan dalam resolusi pengelolaan lingkungan merupakan pekerjaan sistematis serta komprehensif yang bertujuan buat melindungi serta menjauhi pencemaran ataupun kehancuran lingkungan.

Dalam pembentukan peraturan perundang-undangan, norma hukum sangat penting dalam pembentukan hukum yang baik. Norma hukum sendiri diartikan sebagai aturan yang dirumuskan oleh lembaga negara yang berwenang, yang bersifat wajib dan wajib bagi penegakan ketertiban umum. Dibandingkan dengan ketiga norma lain yang disebutkan di atas, ciri khusus dari sanksi yang tegas dan praktis ini merupakan keunggulan norma hukum. Negara memiliki hak untuk menegakkan hukum dan peraturan, dan pelanggar akan dihukum. Ancaman hukuman bisa berupa hukuman bandan atau hukuman objek. Hukuman badan bisa berupa hukuman mati, seumur hidup atau penjara sementara. Selain itu, sanksi lain yang dapat diterapkan antara lain mencabut hak tertentu, menyita barang tertentu dan mengumumkan putusan pengadilan. Untuk menegakkan hukum, negara memiliki aparat penegak hukum. 3 standar lainnya tidak memberikan sanksi tegas dan praktis atas berbagai bentuk hukuman yang disebutkan di atas.

Selain norma hukum terdapat juga kaedah hukum. Kaedah hukum merupakan aturan atau pedoman tentang apa yang harus atau harus dilakukan. Pada hakikatnya Negara Hukum merupakan ekspresi pendapat atau opini tentang bagaimana seseorang harus atau seharusnya bersikap. Sebagai negara hukum, hukum bersifat umum dan pasif.

Perencanaan penggelolaan lingkungsn hidup ialah acuan ataupun pedoman dalam menggunakan, pemeliharaan, pengendalian, pengawasan sumber daya alam buat kepentingan pembangunan. Untuk kepastian hukum dalam pengelolaan lingkungan hidup butuh diberikan landasan hukum yang jelas, perihal ini diakibatkan banyak pihak yang ikut serta dalam pengelolaan lingkungan hidup, baik Pemerintah Pusat, daerah dan warga. Syarat untuk mengendalikan pengelolaan lingkungan hidup ialah UUPLH Nomor. 32 Tahun 2009 serta peraturan pelaksananya, tercantum Peraturan Wilayah berkaitan dengan proteksi serta pengelolaan lingkungan hidup. 


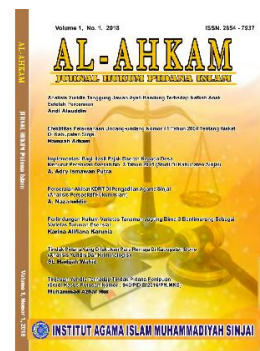

Al-Ahkam

Jurnall Hukum Pidana Islam

Volume 3, No. 1, 2021

ISSN (print) : 2654-7937

ISSN (online) : 2715-0313

Homepage : $\underline{\text { http://journal.iaimsinjai.ac.id/index.php/al-ahkam/index }}$

Manusia sebagai makhluk yang paling bertanggung jawab terhadap kerusakan lingkungan hidup, perbuatan dan tingkah laku serta sifat egois yang ada pada diri manusia sangat mempengaruhi terhadap pola dan tingkah lakunya. Rasa ketidakpuasan dari sifat yang dimiliki selalu menjadi alasan untuk melakukan perbagai perbuatan dalam memenuhi kepentingan hidupnya sehari-hari bahkan dengan merusak lingkungan pun dapat dilakukannya.

Terhadap prilaku manusia semacam yang mengancam kerusakan lingkungan hidup maka pemerintah dalam melaksanakan program pembangunan yang berkelanjutan dengan berwawasan lingkungan harus memberikan perhatian yang lebih serius, karena terhadap prilaku manusia yang demikian bila tidak mendapatkan perhatian yang serius maka justru akan menghambat pelaksanaan pembangunan dan akan menjadi permasalahan yang serius.

Setiap regulasi yang disusun dalam rangka pembangunan di bidang ekonomi harus menginternalisasikan aspek lingkungan, hal ini dimaksudkan untuk menyeimbangkan aspek ekonomi dan aspek lingkungan. Peraturan dalam pelayanan perizinan berusaha terintegrasi secara elektronik, merupakan salah satu regulasi yang memberi payung hukum dalam pembangunan ekonomi, khususnya dalam bidang penanaman modal. Keberadaan Peraturan Pemerintah tersebut ternyata mendapat penolakan dari koalisi masyarakat sipil, seperti Kaoem Telapak, JATAM Kaltim dan lain sebagainya. Bentuk penolakannya adalah dengan mengajukan yudicial review terhadap PP No. 24 Tahun 2018 yang diajukan atau didaftarkan uji materi ke Mahkamah Agung (MA) pada 4 September 2019. ${ }^{2}$ Penolakan tersebut tentunya sudah melalui kajian yang mendalam terhadap sustansi dari peraturan pemerintah ini, yang akan berdampak terhadap lingkungan hidup, sehingga meraka berupaya untuk membatalkan peraturan tersebut melalui yudicial review ke MA.

Hal yang menarik dari mekanisme perizinan yang diatur dalam peraturan pemerintah adalah mengarah pada situasi baru yang disebut komitmen. Komitmen merupakan statment dari pelaksana usaha buat memenuhi persyaratan izin usaha ataupun izin komersial serta operasional. Komitmen yang cuma penyataan dari pelaksana usaha, dijadikan landasan diterbitkannya izin usaha serta izin lingkungan oleh Lembaga OSS.

Secara etimologis, politik hukum merupakan terjemahan dari nama hukum Belanda, yang terdiri dari dua kata recht dan politiek. Kata recht berarti hukum, dan politik termasuk arti beleid yang biasanya diterjemahkan menjadi kebijakan atau kebijakan. $^{3}$ Dengan demikian secara etimologi politik hukum identik dengan kebijakan hukum.

\footnotetext{
${ }^{2}$ https://www.hukumonline.com/berita/baca/lt5d70e7e3c4062/ma-diminta-batalkan-pp-oss/ diunduh tgl16 sep 2020.

${ }^{3}$ Marjanne Termorshuizen dalam Muhammad Akin Politik Hukum Lingkungan Dinamika dan Refleksinya dalam Produk Hukum Otonomi Daerah, PT Raja Grafindo Persada, Jakarta, 2012, hal 1.
} 


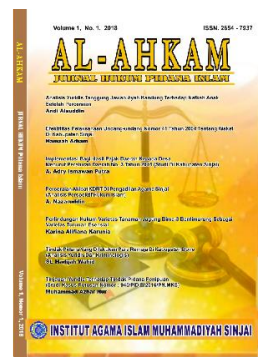

\section{Al-Ahkam}

Jurnal Hukum Pidana Islam

Volume 3, No. 1, 2021

ISSN (print) : 2654-7937

ISSN (online) : 2715-0313

Homepage : $\underline{\text { http://journal.iaimsinjai.ac.id/index.php/al-ahkam/index }}$

Apa yang dikatakan Harold D. Laswel merupakan rencana untuk mencapai tujuan dan nilai dalam praktek perencanaan. ${ }^{4}$ Di sisi lain, bagi David Easton, kebijakan publik merupakan proses pembagian nilai wajib kepada seluruh warga negara, yang dicoba oleh instansi yang berwenang seperti pemerintah. ${ }^{5}$ Berdasarkan pendapat tersebut, maka secara etimologis Politik hukum dapat diartikan sebagai rangkaian tindakan yang direncanakan dan ditetapkan oleh Negara untuk mencapai tujuan, dan juga menentukan arah pembangunan hukum yang akan di buat (ius constituendum).

Konsep politik hukum dalam penelitian hukum memiliki banyak pendapat di kalangan ahli hukum. Menurut Mahfud MD, politik hukum sebagai kebijakan hukum atau jalur formal (policy) yang bertujuan untuk melaksanakan hukum dengan cara membuat undang-undang baru atau mengganti undang-undang lama untuk mencapai tujuan nasional. ${ }^{6}$ Selain itu, Mahfud MD menyampaikan bahwa pengertian politik hukum merupakan kebijakan hukum yang diterapkan oleh pemerintah Indonesia di seluruh pelosok negeri, meliputi: pertama, pengembangan hukum, termasuk penyusunan dan pemutakhiran bahan hukum untuk memenuhi kebutuhan hukum; kedua, hukum yang ada. penegakan hukum termasuk penggunaan lembaga konfirmasi dan bimbingan personel penegak hukum. Terlihat dari kejadian ini bahwa politik hukum meliputi proses pembuatan dan pelaksanaan hukum yang dapat dibuktikan dari sifat dan arah pembentukan dan pelaksanaan hukum. ${ }^{7}$

Politik hukum ialah kebijaksanaan negeri buat mempraktikkan hukum. Konsepsi politik hukum selaku statment kehendak penguasa negeri menimpa hukum yang berlaku di daerah sesuatu negeri serta menimpa arah kemana hukum hendak dibesarkan.

Politik hukum merupakan kebijakan hukum yang telah dilaksanakan oleh pemerintah Indonesia secara nasional. Kebijakan hukum ini mencakup pengembangan hukum sejak awal, yang meliputi pembuatan dan pemutakhiran bahan hukum sesuai dengan kebutuhannya. Kedua, penerapan persyaratan hukum saat ini mencakup konfirmasi penggunaan lembaga dan bimbingan bagi personel penegak hukum. Berdasarkan penjelasan Moh. Mahfud politik hukum meliputi proses pembuatan dan pelaksanaan hukum, yang dapat menunjukkan ciri dan arah pembentukan dan pelaksanaan hukum. ${ }^{8}$ Treori Politik hukum tersebut hendak digunakan buat menganalisis keberadaan peraturan pemerintah pada pelayanan perizinan berupaya terintegrasi secara eletronik.

Kebijakan pengelolaan lingkungan yang digariskan oleh GBHN di atas mengadopsi pendekatan holistik karena menyangkut seluruh aspek lingkungan dan ekosistemnya. Hal semacam ini dirancang untuk mendukung terlaksananya pembangunan agar pembangunan dapat terus dilakukan secara turun-temurun. Pertanyaan yang akan dihadapi adalah bagaimana mengupayakan penerapan kebijakan

\footnotetext{
${ }^{4}$ Harold D. Laswel dalam H. Muhsin dan Fadilah Putra, Hukum dan Kebijakan Publik. Universitas Sunan Giri Surabaya bekerjasama dengan Averroes, Malang, hal 23.

${ }^{5}$ David Easton, ibid.

6 Mahfud MD, Politik Hukum Di Indonesia, Rajawali Pers, PT Raja Grafindo Persada, Jakarta 2009 hal 1

7 Ibid, hal 17

${ }^{8}$ Moh. Mahfud MD, Politik Hukum di Indonesia, PT RajaGrafindo Persada, Jakarta, 2009, hal. 2
} 


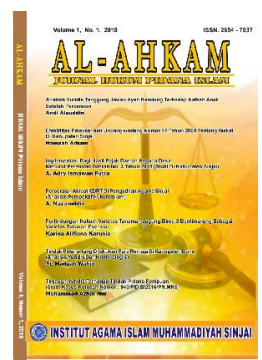

\section{Al-Ahkam \\ Jurnal Hukum Pidana Islam \\ Volume 3, No. 1, 2021 \\ ISSN (print) : 2654-7937 \\ ISSN (online) : 2715-0313 \\ Homepage : $\underline{\text { http://journal.iaimsinjai.ac.id/index.php/al-ahkam/index }}$}

pengelolaan lingkungan dan sumber daya alam semaksimal mungkin dan berkembang secara berkelanjutan secara lingkungan.

Hadirnya Peraturan Pemerintah Mengenai berupaya mengintegrasikan layanan perizinan secara elektronik, tidak terlepas dari kebijakan perekonomian negara Indonesia. Salah satu tujuan pemerintah negara ini adalah memajukan kesejahteraan masyarakat. Diantaranya, amanat ini telah tertuang dalam Pasal 33 UUD Tahun 1945, dan merupakan tugas konstitusional yang menjadi dasar perumusan segala peraturan di bidang ekonomi. Konstitusi menetapkan bahwa pembangunan ekonomi negara saat ini harus berdasarkan prinsip demokrasi dapat melahirkan kedaulatan ekonomi di Indonesia. Ketetapan DPR RI Nomor XVI / MPR / 1998 Nomor XVI / MPR / 1998 yang membahas Sumber Material Undang-Undang Politik dan Ekonomi Dalam Rangka Demokrasi Ekonomi, semakin memperkuat hubungan antara pembangunan ekonomi dan pelaksana ekonomi kerakyatan.

Dalam kaitan ini, investasi wajib sebagai bagian pengelolaan perekonomian nasional, \& wajib dipakai menjadi upaya dalam menaikkan pemulihan perekonomian nasional, membentuk lapangan kerja, mendorong pembangunan ekonomi jangka panjang, menaikkan kemampuan \& keahlian teknis nasional, mempromosikan pembangunan sosial \& ekonomi, \& mencapai pertumbuhan ekonomi. Kesejahteraan rakyat sendiri terletak pada ekonomi kompetitif.

Dengan adanya koordinasi antara instansi pemerintah pusat dan daerah, pembentukan birokrasi yang efektif, kepastian hukum di bidang penanaman modal, belanja ekonomi yang kompetitif, usaha yang menguntungkan di bidang ketenagakerjaan dan pengamanan usaha, dengan revisi berbagai aspek penunjang, dapat meningkatkan realisasi investas.

Masalah utama dalam berinvestasi di Indonesia adalah masalah legalisasi dan perizinan. Sehubungan dengan hal tersebut, pemerintah mengeluarkan UndangUndang tentang Penanaman Modal. Undang-undang ini mengatur masuknya layanan terintegrasi yang komprehensif. Dengan sistem ini diharapkan pelayanan terpadu di tingkat pusat dan daerah dapat mempermudah perizinan dan mempercepat penyelesaiannya. Untuk memenuhi persyaratan tersebut, pemerintah mengumumkan "Peraturan Layanan Perizinan Pemerintah" untuk mencapai integrasi elektronik. Tujuan dibentuknya Peraturan Pemerintah untuk meningkatkan pelayanan PTSP yang diberikan kepada pemerintah pusat dan pemerintah daerah agar lebih efisien, efektif dan modern, yaitu dengan menyediakan sistem pelayanan perizinan electronic single submission OSS (online single submission OSS). Melalui OSS, pelaku ekonomi mendaftarkan dan mengelola pemberian izin usaha serta pemberian izin usaha dan / atau izin usaha secara terintegrasi. Pemerintah pusat dan pemerintah daerah juga telah menerbitkan izin usaha yang diajukan oleh pelaku ekonomi melalui OSS.

Menunjukkan bahwa pedoman bertentangan satu sama lain. Undang-Undang tentang kedudukan perlindungan dan pengelolaan lingkungan, menganggap AMDAL dan UKL-UPL sebagai prasyarat untuk memperoleh izin lingkungan. Artinya kajian AMDAL dan UKL-UPL telah dilakukan dengan benar, dan setelah Panitia Evaluasi Amdal memberikan rekomendasi ramah lingkungan, rekomendasi tersebut dijadikan dasar untuk penerbitan izin lingkungan. Bertentangan dengan prinsip hukum dalam peraturan izin komersial dan izin lingkungan harus diterbitkan terlebih dahulu, disusul 


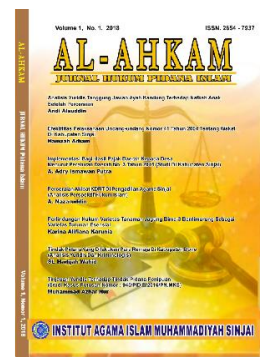

AMDAL dan UKL-UPL. Selain itu asas hukum tidak sesuai dengan logika hukum, juga tidak bertentangan dengan doktrin hukum administrasi nasional yang harus terlebih dahulu memenuhi persyaratan perizinan, karena menyangkut legalitas perizinan yaitu perintah administratif negara.

Berdasarkan hal tersebut jelas menunjukan bahwa eksistensi Peraturan Pemerintah Nomor 24 Tahun 2018 tentang Pelayanan Perizinan Berusaha Terintegrasi Secara Eletronik memberikan dasar hukum bagi pemerintah untuk menarik investasi sebesar-besarnya dalam mewujudkan pertumbuhan ekonomi negara dan masyarakat, dengan melakukan penyederhanaan perizinan usaha.

\section{Kesimpulan}

Dalam perumusan Peraturan Pemerintah Nomor 24 Tahun 2018 mengenai pelayanan perizinan niaga terintegrasi secara elektronik. Dalam hal ini perlu memperhatikan peraturan perundang-undangan terkait, yaitu melalui sinkronisasi vertikal dan horizontal untuk mewujudkan esensi peraturan tersebut tidak. konflik satu sama lain, mudah dilaksanakan, dan memberikan kepastian hukum.

Terkait dengan hambatan perizinan berusaha, yang perlu dilakukan adalah dengan mereformasi birokrasi agar tidak mempersulit pelaku usaha dalam pengurusan perizinan berusaha dan juga penegakan hukum tegas terhadap pungli dan/atau korupsi yang dilakukan oleh pejabat dan/atau staf dalam birokrasi tersebut.

Kebijakan pemerintah dalam merumuskan Peraturan Pemerintah ini, dilandasi semata-mata mengejar peningkatan pertumbuhan ekonomi nasional dan ciptakan lapangan kerja agar mengurangi pengangguran dengan cara menarik investasi sebesarbesarnya serta melakukan penyederhanaan perizinan usaha dengan mengabaikan aspek lainnya terutama aspek kelestarian lingkungan hidup, melainkan harus bersinergi dengan prinsip pembangunan berwawasan lingkungan. 


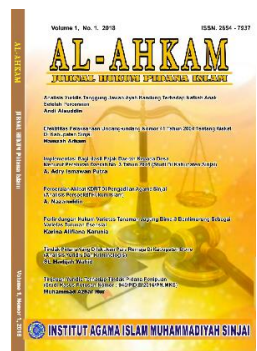

\section{Daftar Pustaka}

Buku :

Izhandri, S., Kn, M. and Agustina, D. (2018) 'OSS dan Perkembangannya di Indonesia OSS and Its Development in Indonesia', (1).

Amrah Muslimin, Beberapa Asas dan Pengertian Pokok Administrasi dan Hukum Administrasi, Alumni Bandung, 1985.

Bambang Antariksa,Penerapan Hierarki Peraturan Perundang-Undangan Dalam Ketatanegaran Indonesia.

Daut silalahi , Hukum Lingkungan Dalam Sistem Penegakan Hukum Lingkungan Indonesia, Alumni Bandung, 2001.

H. Muhsin dan Fadilah Putra, Hukum dan Kebijakan Publik. Universitas Sunan Giri Surabaya bekerjasama dengan Averroes, Malang.

Jimmly Asshiddiqie, Perihal Undang-Undang, Rajawali Pers, Jakarta 2011

Koesnardi Hardjasoemantri, Pengantar Hukum Tata LinggkunganHukum, Edisi Ketujuh, Gadjah Mada University Press, 2001.

Maria farida, Ilmu perundang-undangan, dasar-Dasar dan Pembentukannya, Kanisius, Yogyakarta, 1998.

Mahfud MD, Politik Hukum Di Indonesia, Rajawali Pers, PT Raja Grafindo Persada, Jakarta 2009.

Muhammad Akin Politik Hukum Lingkungan Dinamika dan Refleksinya dalam Produk Hukum Otonomi Daerah, , PT Raja Grafindo Persada, Jakarta, 2012.

N.H.T. Siahaan, Hukum Lingkungan, Pancur Alam Jakarta, 2009.

N.M. Spelt dan J.B.J.M. ten Berge, pengantar Hukum perizinan, disuting oleh Philipus M. Hadjon, Yuridika Serabaya. 1993.

Purnadi Purbacaraka dan Soejono Soekanto, Perihal Kaidah Hukum, Alumni, Bandung 1982,

Philipus M. Hadjon, Pengantar Hukum Administrasi Indonesia, Gadjah Mada University Press, 1993.

Prajudi Admosudirdjo, 1988, Hukum Administrasi Negara, cetakan 9, Ghalia Indonesia , Jakarta.

Piter Mahmud Marjuki, 2007, penelitian Hukum, kencanaPrenada Media Group, Jakarta.

Ridwan HR, Hukum Administrasi Negara, PT Raja Grafindo Persada, Jakarta, 2002 .

Susdikno Mertokusumo,2001, Penemuan Hukum Sebuah Pengantar, Liberty Yogyakarta.

Sjahran Basah, Eksistensi dan Tolok ukur Badan Peradilan Administrasi di Indonesia, Alumni, Bandung, Cet ke 3, 1997.

ST. Marbun dan Moh. Mahfud. MD, Pokok-Pokok Hukum administrasi 
Homepage : http://journal.iaimsinjai.ac.id/index.php/al-ahkam/index

\section{Website :}

https://www.alinea.id/bisnis/ini-program-ekonomi-jokowi-dalam-nawacita-jilid-iib1Xbu9hTo

http://web.unair.ac.id/admin/file/f 20025 a1.ppt

https://www.hukumonline.com/berita/baca/lt5d70e7e3c4062/ma-diminta-

batalkan-pp-oss

Peraturan Perundang-undangan :

UU No 32 Tahun 2009 Tentang Perlindungan dan Pengelolaan Linggkungan Hidup PP No 27 Tahun 2012 Tentang Izin Lingkungan.

PP No. 24 Tahun 2018 tentang Pelayanan Perizinan Berusaha Terintegrasi Secara Elektronik 